\title{
TRADE AND DEVELOPMENT IN A LABOR SURPLUS ECONOMY
}

\author{
EDWARD B. BARBIER \\ MICHAEL RAUSCHER
}

CESIFO WORKING PAPER NO. 1481

CATEGORY 7: TRADE POLICY

JUNE 2005
An electronic version of the paper may be downloaded
- from the SSRN website:
www.SSRN.com
- from the CESifo website: www.CESifo.de




\title{
TRADE AND DEVELOPMENT IN A LABOR SURPLUS ECONOMY
}

\begin{abstract}
This paper looks at a model in which two countries trade agricultural and manufactured commodities. The manufactured-goods sector produces with increasing returns to scale under conditions of monopolistic competition. It is shown that an increase in land endowment (or an increase in agricultural productivity) can have negative welfare implications for both countries. This outcome can result under three different scenarios: asymmetries across countries, i.e. a North-South model, a neoclassical labor market in the home country's instead of a Lewisian market, and alternative utility functions.
\end{abstract}

JEL Code: F12, J61, O15, O18.

Keywords: international trade, labor surplus economy, land expansion, monopolistic competition, North-South model.

Edward B. Barbier

Department of Economics and Finance

University of Wyoming

Department 3985, Ross Hall 123

Laramie, WY 82071

USA

ebarbier@uwyo.edu
Michael Rauscher

Department of Economics

University of Rostock

Ulmenstr. 69

18057 Rostock

Germany

michael.rauscher@uni-rostock.de

The authors thank Wilhelm Kohler and Karlhans Sauernheimer for helpful comments and suggestions. The usual disclaimer applies. 


\section{Introduction}

One of the earliest contributions of the post-war development economics literature was the characterization of developing countries as dualistic economies dominated by labor-surplus conditions. The initial closed-economy models lead to inherently optimistic conclusions: Any "unlimited supplies" of labor in the traditional, or agricultural, sector would be absorbed through expansion of the modern sector expansion, and the economy would eventually "take off" into sustained growth (Lewis 1954). More recent contributions have extended the Lewisian conditions of a labor-surplus developing economy to "North-South" models of trade and capital flows (e.g. Findlay, 1980, Burgstaller and Saavedra-Rivano, 1984) where "a growing industrial North is linked to and transmits growth impulses to a primary-goods producing South via the terms of trade and international capital mobility" (Findlay and Lundahl 1999, pp. 5-6). However, other two-sector (agriculture and manufacturing), two-country models suggest that HeckscherOhlin trade conditions may also coincide with "unequal development" between two regions, especially if one sector (manufacturing) is subject to increasing returns to scale. For example, Krugman (1981, p. 149) has demonstrated how trade may reinforce and sustain the economic dominance of the leading region, as "a small 'head start' for one region will cumulate over time, with exports of manufactures from the leading region crowding out the industrial sector of the lagging region." Similarly, Matsuyama (1992) establishes that, when a two-sector economy with freely mobile labor opens to trade and has an initial comparative advantage in agriculture, a negative link is establishing between rising agricultural productivity, manufacturing employment and economic growth. In an open economy with more productive agriculture (relative to the rest of the world) the agricultural sector squeezes out manufacturing, and the economy declines.

The following paper also explores trade and development linkages in a two-country, twosector setting that retains many of the standard features common to neoclassical North-South models. However, we introduce four important innovations. First, although the agricultural sector is perfectly competitive and produces a homogeneous good under constant returns to scale production from land and labor, we introduce the "labor surplus" characteristics of a Lewisian model. We represent this condition in the normal way be assuming that agricultural labor is sufficiently abundant so that its average productivity equals the wage rate. Second, as in the case of the models by Krugman (1981) and Matsuyama (1992), we allow for increasing returns to scale in manufacturing, but at the firm and not the industry level. We assume that manufacturing 
is monopolistically competitive, and firms produce many varieties under increasing returns to scale. Third, we allow for perfect labor mobility between the two sectors. This means that, given the presence of labor surplus conditions in the agricultural sector, any increase in the labor force is absorbed by manufacturing and not agriculture. Finally, unlike either Lewisian labor surplus models or current North-South models, we consider explicitly the role of an increase in the fixed factor, land. Under labor surplus conditions, an increase in the availability of land is the only way that a rise in agricultural output per worker will occur.

Thus, the main aim of the following paper is to examine whether an increase in land and agricultural productivity will lead to gains or losses from trade and development from the labor surplus economy. We derive our main results assuming that the two trading partners are symmetric: all parameters of the production and utility functions for both the home and foreign country are identical. Only the change in the endowment of the home economy with land introduces an asymmetry, which consistent with Heckscher-Ohlin conditions, also ensures that in the new equilibrium the home country becomes an exporter of agricultural goods and a net importer of manufactures. However, although the assumption of symmetry is analytically convenient for tractability, we also show that our results do not change fundamentally when we introduce the possibility that agricultural production in the foreign economy is not subject to labor surplus conditions.

We begin with the simplest variant of the model in which the utility function of consumers is quasi-linear such that the demands for domestic and foreign manufacturing varieties are independent of income. This version produces a result similar to that of Matsuyama (1992). An increase in agricultural productivity in the home country via a change in its land endowment leads to an expansion in agricultural production and employment, and consequently the manufacturing sector and employment contract. However, unlike in Matsuyama's model, we have the additional effect that, although production and employment in the rest of the world (i.e. the foreign country) is unchanged, foreign welfare also declines as consumers enjoy less imported varieties. Thus both countries are worse off, and in fact suffer equal welfare losses.

We consider also an alternative version of quasi-linear preferences in which the demand for the agricultural good is independent of income. The effects of a change in land in the home country are unambiguous under two special cases only. 
In the case that demand for the agricultural commodity is very price inelastic in both countries, an increase in the land endowment of the home country leads to a substantial increase in the relative world price for manufactured goods, and as a result, workers shift from agriculture to manufacturing. This leads to more product variety, and since the increase in agricultural productivity exceeds the loss of labor, there is also a rise in agricultural output. Thus, everyone is better off. This result produces a similar optimistic outcome for the labor surplus economy as the original model of Lewis (1954), although our result depends on an entirely different mechanism of an expansion in agricultural land rather than population growth and we obtain the usual open economy condition that the more land abundant economy becomes the net agricultural exporter.

We also obtain unambiguous results in the case that a specific, fixed proportion of global manufacturing labor income must be spent on agricultural goods. In this variant, an expansion of land in the home country does not affect relative prices or foreign product variety, but it does reduce manufacturing varieties produced domestically. There is a tradeoff between increased agricultural goods and this decline in product variety. As a result, if the latter impacts dominate, then welfare in both countries will decline.

In sum, we show that the effects of an increase in land availability on trade and development in a labor surplus economy are subject to a number of possible outcomes. Depending on modeling assumptions and parameters, these results can range from the "immiserizing growth" depicted by Matsuyama (1992) to the optimistic "growth takeoff" predicted by the original labor surplus model of Lewis (1954). In addition, we demonstrate that these fundamental results will hold, even if only one trading partner (the home country) is subject to labor surplus conditions. There are, however, a number of important extensions that could be explored with this model, and we try to identify some of the more pertinent ones for further research.

The paper is organized as follows. The next section develops the general features of the two-sector, two-country trade model. Section 3 discusses the version of the model in which demands for home and foreign manufacturing varieties are independent of income, and Section 4 examines the alternative case where the demand for agricultural goods is independent of income, but demand for differentiated manufactured goods is income elastic. Section 5 extends this to a 
North-South trade model with differentiated countries. The concluding Section 6 makes some final remarks.

\section{The Model}

In what follows, we will consider a two-country two-sector model of international trade. The following section models the two sectors of the economy and the factor market. We then proceed by looking at the simplest variant of the model: the utility function is quasilinear and the demand for the manufactured good is independent of income. It will be shown that an increase in the availability of land unambiguously leads to welfare losses. Afterwards, we consider a more realistic version of the model in which demand for manufactured goods is income-independent.

We start with the assumption that the countries under consideration are perfectly symmetric; all parameters of the production and utility functions are identical. Only the change in the endowment of the home economy with land introduces an asymmetry. Later on, additional asymmetries will be introduced. The model will be explained for the case of the domestic economy. The corresponding equations for the foreign country follow by analogy. Variables of the foreign country will be indicated by asterisks.

The countries produce two goods: an agricultural commodity and a manufactured good. The agricultural commodity is the numéraire. Its price is unity, and the price of the manufactured good as well as factor incomes is measured in terms of this numéraire. Let the total labor supply in each country be 1 and let $L$ denote the share of labor employed in manufacturing. Assuming no unemployment, this means that $(1-L)$ is employed in the rural sector.

\subsection{Agriculture}

Agricultural production requires two factors, land, $N$, and labor, 1- $L$. The two factors are combined via a constant-returns-to-scale Cobb-Douglas production function to yield output $Q^{A}$

$$
Q^{A}=N^{\alpha}(1-L)^{1-\alpha},
$$

where $\alpha$ is the output elasticity of land. As mentioned in the introduction, there are no conventional markets for land and rural labor. People living in the rural area appropriate land and 
harvest the fruit of their work on this land. Thus the income of a rural household, $w^{A}$, measured in units of the agricultural good, equals the average productivity of labor

$$
w^{A}=N^{\alpha}(1-L)^{-\alpha}
$$

This relationship also implies that land rent is completely "dissipated"; i.e., all available land rent is subsumed in the wage income of rural households. Note that factor remuneration according to the marginal-productivity rule would change this condition only slightly: a factor (1- $\alpha)$, which is less than one, would occur on the right-hand side of this equation. The marginal productivity is less than the average productivity. This implies that rural labor supply is larger in a regime with average-productivity remuneration than with marginal-productivity wages. The above conditions constitute the labor surplus characteristics of the agricultural sector.

\subsection{Manufacturing}

We model the manufacturing sector following the monopolistic competition approach of Dixit and Stiglitz (1977). Manufactured goods are produced under increasing returns to scale at the firm level. There is a large variety of "similar" manufactured goods, the number or "mass" of these commodities being $n$ in the home country and $n^{*}$ in the foreign country. Manufactured varities are good substitutes for each other and consumers like variety. We will later on model consumer utility explicitly, employing two different assumptions concerning individual preferences for commodities. For the time being, it is sufficient to note that the inverse market demand function for a representative manufacturing variety is

$$
p=\xi q^{\gamma-1}
$$

where $\gamma$ is a parameter of the utility function, $0<\gamma<1$, and $\xi$ is a parameter taken as given by the individual producer which contains income effects and a general price index. From $0<\gamma<1$, it follows that the demand for this variety is price elastic: $(\gamma-1)^{-1}<-1$.

The production process uses labor as the only factor of production. We assume increasing returns to scale at the firm level. The total labor employed by a representative firm is

$$
l=F+v q
$$

where $F$ denotes the fixed labor requirement necessary to produce this variety, $q$ is the output and $v$ is a constant. With $w^{M}$ being the wage rate in the manufacturing sector, the total cost of 
producing $q$ is $(F+v q) w^{M}$. Using the inverse demand function (3), the representative firm's profits turn out to be

$$
\pi=\xi q^{\gamma}-(F+v q) w^{M}
$$

The firm maximizes profits with respect to output, $q$. The first-order condition is $p=\gamma^{-1} v w^{M}$,

where $p$ has been inserted for $\xi q^{\gamma-1}$. This yields the standard result that each firm charges a monopoly mark-up over marginal cost and the mark-up factor is $\gamma^{-1}>1$. The mark-up pricing equation can be re-written such that the price of the manufactured good determines the wage rate in this sector

$$
w^{M}=\frac{p \gamma}{v} .
$$

Free entry and exit lead to zero profits. Together with (5), this determines the output per firm

$$
q=\frac{\gamma}{1-\gamma} \frac{F}{v} .
$$

This result is also standard for a Dixit-Stiglitz model of monopolistic competition. The output of the firm depends on the parameter of the demand function and on the ratio of fixed to variable costs. Since these parameters of the model do not change, $q$ is constant and does not depend on prices or other variables that might be affected by changes in factor endowments. In addition, given the assumption that the parameters are the same at home and abroad, it follows that $q^{*}=q$.

\subsection{Product Variety and Labor Market Equilibrium}

Product variety is limited by the scarcity of the factors required for production of manufactured goods. Thus $L=n l$. Inserting for $l$ and using (6) to eliminate $q$ yields

$$
L=\frac{n F}{1-\gamma} .
$$

Total labor demand in manufacturing is determined by fixed cost, the number of firms, and the preference parameter $\gamma$. Although we have increasing returns at the firm level, there are constant returns to scale at the industry level in the monopolistically competitive equilibrium. As we have shown, the output of each firm depends on exogenous parameters and is constant. Labor demand 
in manufacturing is linearly increasing in the number of varieties and thus in the total output of the industry.

We assume that workers are mobile within countries but not across national borders. Intersectoral mobility implies equal wages in the two sectors, i.e. $w^{M}=w^{A}=w$. From (2) and (5), we have that

$$
w=\frac{\gamma}{v} p=\left(\frac{N}{1-L}\right)^{\alpha} .
$$

This result is depicted in Figure 1. The horizontal axis shows the domestic economy's labor supply and its allocation to the two sectors. The wage rate in agriculture is a decreasing function of rural employment since average productivity $(A P)$ is a declining function of labor

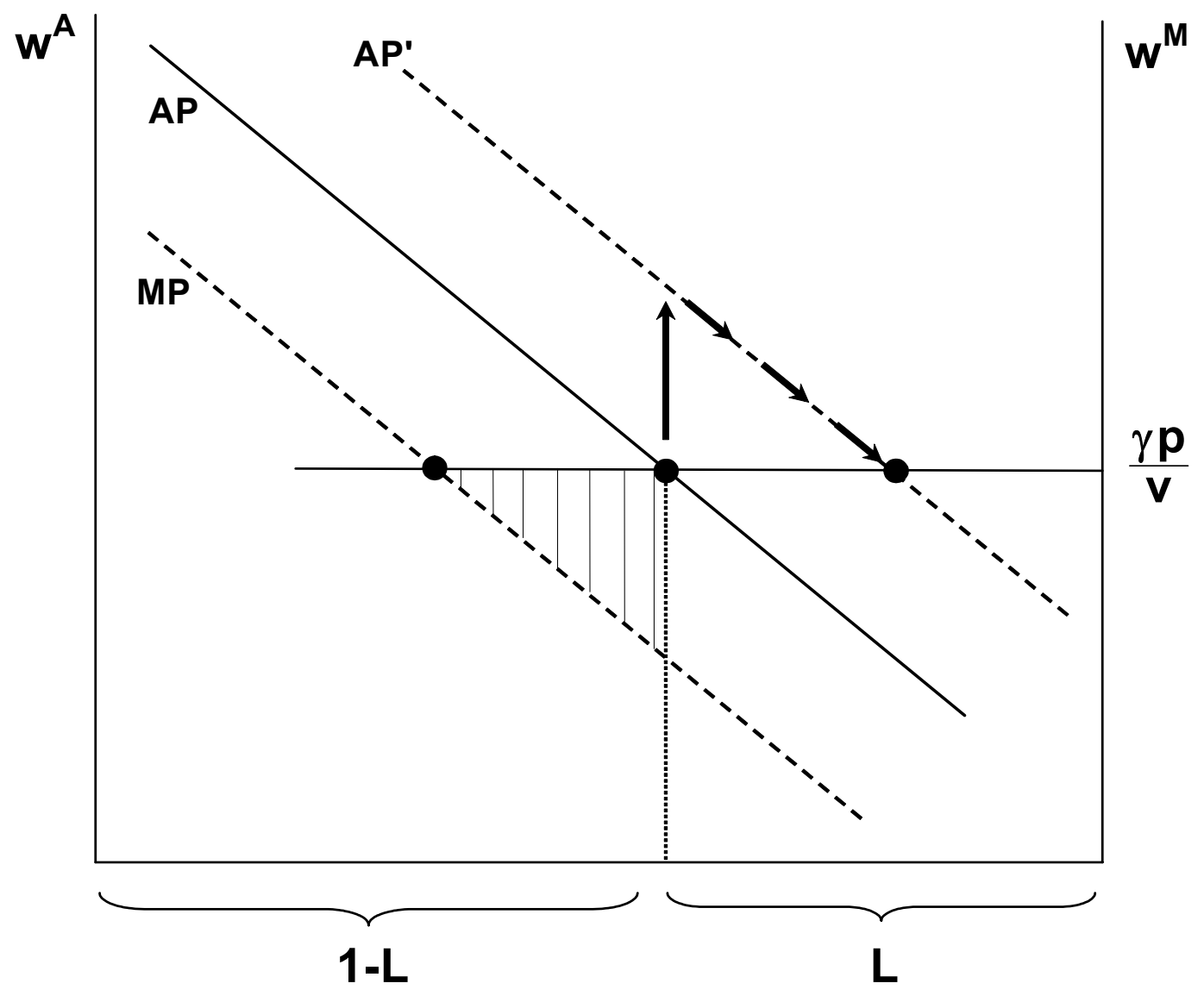

Figure 1: The labor market in the home country 
input. The horizontal line is the manufacturing wage, which from (8) is proportional to the price of the manufactured good. It will be shown later that this price is indeed independent of the allocation of labor. The intersection point of the wage rate and the $A P$ curve determines the migration equilibrium and the allocation of labor between the two sectors. If the agricultural wage is instead determined by marginal productivity $(M P)$, the rural labor demand curve would be lower and less labor would be employed in agriculture. The distance between these two equilibria determines the amount of agricultural surplus labor. In a competitive economy, the welfare loss due to the existence of any surplus labor would be the shaded triangle. ${ }^{1}$

Equation (8) is essential for the derivation of the key comparative static results of our model. If the effects of a change in land endowment, $N$, on the price, $p$, (and on the foreign price, $p^{*}$ ) are known, then the effects of a change in $N$ on the labor market can be determined. Then the effects on product variety follow from equation (7) and its foreign equivalent. In order to derive these price effects, however, a closer look at the demand side is required. The next two sections examine in turn two different scenarios concerning consumer preferences: a utility function with quasilinear preferences in agricultural consumption and a utility function with the manufactured good as a luxury commodity.

\section{Preferences: A Utility Function Quasilinear in Agricultural Consumption}

The first scenario is a quasilinear utility function. Let $A$ denote the demand for agricultural goods and let the utility of a representative individual, $U$, be

$$
U=A+\frac{1}{\gamma}\left(n c^{\gamma}+n^{*} m^{\gamma}\right),
$$

where $c$ denotes consumer demand for a representative domestic variety of the manufactured good and $m$ stands for import demand for a representative foreign variety. As before $n$ and $n *$ are the domestic and foreign numbers of varieties. The parameter $\gamma$ measures the degree to which consumers regard different varieties as substitutes, and $(1-\gamma)^{-1}$ is the elasticity of substitution among varieties. Assume that commodities are internationally tradable at negligible cost. Then the budget constraint of the representative consumer is

1 The shift from $A P$ to $A P^{\prime}$ will be discussed in the next section of the paper. 


$$
w=A+n p c+n * p * m
$$

with $w$ denoting labor income. As already explained, land rent is considered as a part of rural labor income, and is subsumed in the factor remuneration equation (2). Inserting the budget constraint into the utility function gives

$$
U=w+\frac{1}{\gamma}\left(n c^{\gamma}+n^{*} m^{\gamma}\right)-n p c-n^{*} p^{*} m .^{2}
$$

Via utility maximization, consumer demand functions for domestic and foreign varieties are then determined respectively as

$$
c=p^{\frac{1}{\gamma-1}}
$$

and

$$
m=p^{\frac{1}{\gamma-1}}
$$

Indirect utility turns out to be

$$
U=w+\frac{1-\gamma}{\gamma}\left(n p^{\frac{\gamma}{\gamma-1}}+n * p^{\frac{\gamma}{\gamma-1}}\right)
$$

which is decreasing in prices and increasing in product variety and wage income.

Using the demand functions for domestic and foreign goods in the two countries, one can derive the market demands for representative domestic and foreign varieties of the manufactured good. There is intra-industry trade like in Krugman (1979 and 1980). For the home country,

2 Note that this is a simplified version of the original utility function. Originally, each individual faces the possibility to choose from a continuum of commodities and the utility function is

$$
U=Y+\frac{1}{\gamma}\left(\int_{0}^{n}(c(i))^{\gamma} d i+\int_{0}^{n^{*}}(m(i))^{\gamma} d i\right)-\int_{0}^{n} p(i) c(i) d i-\int_{0}^{n^{*}} p^{*}(i) m(i) d i .
$$

To save on notation, we use (9) instead. It is a standard result, that all prices $p(i)$ and all consumer demands $c(i)$ and $m(i)$ are identical ex post if these commodities are produced via the same technological processes. We do not derive this result again, but use it to simplify notation from the beginning. 
market demand for a variety is the sum of domestic demand and foreign demand, $q=c+m^{*}$, and for the foreign country, $q^{*}=c^{*}+m$. Using equations (6), (10a), and (10b), we can establish that

$$
p=p^{*}=\left(\frac{\gamma F}{2(1-\gamma) v}\right)^{\gamma-1}
$$

where $p=p^{*}$ follows from $q=q^{*}$. The scalor 2 in the denominator is explained by the fact that the total size of the labor force in both countries, which determines global demand, is 2.

We will now introduce a change in the land endowment in the domestic economy. This may be interpreted literally, e.g. that additional land becomes available by extending the "land frontier" of the economy. ${ }^{3}$ The change in land endowment may, however, also represent a change in agricultural productivity as is evident from (2). The standard intuition is that such a change relaxes the economy's resource constraint and is, therefore, welfare-improving. The following proposition shows that this is not true for our model.

\section{Proposition 1}

Assume that utility is linear in agricultural demand. Then an increase in land has the following effects:

(a) The prices of manufactured goods and the number of foreign varieties remain constant.

(b) Labor leaves the manufacturing sector such that the labor-land ratio remains constant in agriculture:

$$
\frac{d(1-L)}{d N}=\frac{1-L}{N}
$$

(c) The number of domestic varieties is reduced:

$$
\frac{d n}{d N}=-\frac{(1-\gamma)(1-L)}{F N}
$$

(d) Welfare is reduced in both countries.

3 See Findlay and Lundahl (1999) for discussion of how this "expanding" land frontier has influenced economic development historically. In the US, settlers moved westward in the 19th century and appropriated arable land in the west, ranging from the prairies to the Pacific Coast. Similar rapid arable land expansion also occurred in other "regions of recent settlement" in the late $19^{\text {th }}$ and early $20^{\text {th }}$ centuries, notably Canada, Argentina and Australia. In many of today's developing countries the land frontier is still being extended by clear-cutting tropical forests and converting wetlands and other "natural" habitat (Barbier 2005). 
(e) The home country becomes an exporter of agricultural goods and a net importer of manufactured goods.

Proof: Constancy of prices in (a) follows from (11). With a constant foreign price, the foreign equivalent of equation (8) implies that $L^{*}$ is constant. Constancy of $n^{*}$ then follows from (7). Part (b) follows from (8). Part (c) then follows from (12a) and (7). The part (d) result, that both countries are worse off, follows from the fact that indirect utility, equation (10), is increasing in product variety, (11). Part (e) follows from the fact that $m=m^{*}\left(\right.$ since $\left.p=p^{*}\right)$. Since $n$ is reduced, $n m^{*}<n^{*} m$ in the new equilibrium. Foreign imports of manufactured goods are smaller than domestic imports.

Explanation. Figure 1 can be used to illustrate Proposition 1. The increase in land endowment causes the $A P$ curve to shift upwards to $A P^{\prime}$. As additional land becomes available, rural labor income is increased and people move into the agricultural sector to appropriate this land. Prices of manufactured goods, however, remain constant since the quasilinear utility function implies that demand for manufactured goods is income inelastic. Thus, the change in rural labor income has no effects on the market for manufactured goods. Since prices of manufactured goods remain unchanged, foreign producers have no incentives to change their supply. Constant manufacturedgoods prices moreover imply constant industrial wages. As more and more people move into the rural sector, rural incomes decline. In the long-term migration equilibrium, which is to the right of the original equilibrium, rural wages equal manufacturing wages once again. People have the same incomes as in the initial equilibrium, but more people than before reside in the rural region. Output of agricultural commodities has increased. Manufactured-goods output has been reduced via a reduction in the number of varieties. Since consumers love variety, they experience welfare losses. This affects not only domestic but also foreign consumers. Thus, everyone is worse off. Trade evolves according to the standard Heckscher-Ohlin patterns. The home country, which is now more abundant in land, exports the land-intensive commodity.

The welfare loss is a typical second-best result. Surplus labor in agriculture implies that relaxing the restriction of land availability has harmful effects. Additional workers are drawn into a sector that is already characterized by surplus labor. The marginal worker's productivity in agriculture is less than the value of her productivity in manufacturing. Thus, it is not surprising 
that welfare effects are negative for the home country. ${ }^{4}$ It is surprising, however, that the foreign country loses, too. In standard factor-proportions models of international trade, the other country would always benefit when domestic factor endowments are changed in a symmetric equilibrium. It would move from autarky to trade and it would benefit from the possibility to import agricultural commodities at low prices. In our model, in contrast, there is trade in the initial equilibrium already. This trade results in a large number of varieties that foreign consumers can choose from. As domestic labor force moves to agriculture, product variety is reduced and consumers in the foreign consumers find themselves worse off - as do domestic consumers.

Can this result be generalized? Three possibilities are considered: asymmetries across countries, i.e. a North-South model, a neoclassical labour market in the home country's instead of a Lewisian market, and alternative utility functions.

First, one might wish to discard the assumption of symmetry. Our model assumes that both countries are developing countries with a Lewisian agricultural sector in which labor is remunerated according to average productivity. One alternative is that the foreign country is an industrial country with a neoclassical rural labor market and - perhaps - higher levels of productivity in the two sectors. It can easily be seen that all these changes do not affect the model's results as long as both countries have identical quasilinear utility functions. In this case, prices for differentiated goods still depend only on technical parameters, the $\gamma$ parameter of the utility function and on the number of households. If these parameters are constant, relative prices are constant. It follows that industrial wages are constant, too. Thus, migration of domestic workers to the rural sector can have no effects on income. As in the symmetric model, the only effect relevant for consumer welfare in both countries is the loss of variety.

Second, one might assume that the home country has neoclassical rural labor and land markets. The factor-price equations are

$$
w^{A}=(1-\alpha)\left(\frac{N}{1-L}\right)^{\alpha}
$$

4 This result is closely related to Johnson's (1967) immiserizing growth result. In Johnson's analysis, the distortion was due to a tariff that protected the growing sector and lead to an extensive use of factors in this sector. 


$$
r=\alpha\left(\frac{N}{1-L}\right)^{\alpha-1}
$$

where $r$ denotes land rent. With a change in domestic land endowment, parts (a), (b), and (c) of Proposition 1 remain unchanged. This implies that the rural land-labor ratio is constant and, therefore, $r$ is constant, too. Land rent income, $r N$, however, is increased and this affects the welfare result:

\section{Proposition 2}

Assume that utility is linear in agricultural demand and let the factor wages in agriculture equal their marginal productivities. Then the welfare effects of an increase in land are ambiguous in the home country and negative in the foreign country.

Proof. The welfare loss of the foreign country follows from the fact, that from its perspective the only variable that changes is the number of domestic varieties. The result for the home country is proved in Appendix A.1.

Explanation. The increase in land rent raises real income, which is beneficial. However, the resulting welfare gains may still be offset by the loss of product variety, in particular if varieties are bad substitutes for each other and consumers have a strong preference for a large degree of product variety. In contrast to the traditional immiserizing-growth argument developed by Johnson (1967), the possibility of welfare losses arises from imperfect competition in the sector not affected by factor expansion. The welfare loss spills over to the other country via a loss of variety.

Finally, one might wish to look at alternative specification of preferences. From the discussion of the effects of potential changes in the model assumptions, it becomes obvious that the quasilinearity of the utility function is decisive for the results. The quasilinear utility function used here implies that all additional income is spent on food and that, therefore, prices remain unchanged. Unfortunately, the assumption of quasilinear utility is not particularly realistic. In reality, one would expect food to be a good satisfying basic needs, i.e. having a low income elasticity, and demand for manufactured goods to capture the major share of additional 
expenditure when income is increased. The next section will be devoted to an alternative specification of the model in which the manufactured good, not food, is a luxury good.

\section{Alternative Preferences: The Manufactured Good as a Luxury Good}

Assume a utility function of the following type

$$
U=\frac{A^{1-\delta}-1}{1-\delta}+\left(n c^{\gamma}+n * m^{\gamma}\right)^{\frac{1}{\gamma}},
$$

where $\delta>0$. If $\delta=1$, the first component of the utility function is $\ln A$. Note that the second component of the utility function is linearly homogenous in $c$ and $m$. Again note that this is a short representation of a more complicated utility function including an integral of individualvariety utilities over the range of available varieties. The budget constraint is the same as before (equation (9)). Utility maximization gives the demand equations and the results derived in Section 2 can be used to determine the equilibrium (see Appendix A.2)

$$
\begin{aligned}
& p=p^{*} \\
& w=w^{*} \\
& c=m=c^{*}=m^{*}=\frac{q}{2}=\frac{q^{*}}{2} \\
& A=A^{*}=\left(n+n^{*}\right)^{\frac{\gamma-1}{\gamma \delta}} p^{\frac{1}{\delta}} \\
& \left(n+n^{*}\right) p q+2 A=2 w
\end{aligned}
$$

Equality of prices, (16a), follows from symmetry and the absence of transport costs. Wages, (16b), are determined by prices. Symmetry and the absence of transport cost also imply that imports, exports, and consumption of domestically produced goods are equal in both countries, (16c). Equation (16d) shows that the demand for the agricultural good is income-independent. The price elasticity depends on the preference parameter $\delta$. Since $p$ is the price of the manufactured good in terms of the agricultural good, the demand for agricultural commodities is increasing in $p$. Moreover, demand for agricultural commodities is a decreasing function of 
manufactured goods variety $\left(n+n^{*}\right)$. Equation (16e) is the budget constraint for world income, the left-hand side being expenditure and the right-hand side being income.

Inserting into (16e) for $w$, from equation (5), for $q$ from equation (6), and for $A$ from equation (16d), we have

$$
\frac{\gamma}{v} p\left[2-\frac{F}{1-\gamma}\left(n+n^{*}\right)\right]=2\left(n+n^{*}\right)^{\frac{\gamma-1}{\gamma \delta}} p^{\frac{1}{\delta}}
$$

as a condition for the goods-market equilibrium. Besides $p$, the other two unknowns in (17) are $n$ and $n^{*}$. These variables are determined via the rural labor market condition (8) and its foreign analogue. Noting that prices and wages are internationally identical, the domestic and foreign factor market equilibrium equations can be rewritten slightly

$$
\begin{aligned}
& \frac{\gamma}{v} p=\left(\frac{N}{1-L}\right)^{\alpha}=\left(\frac{(1-\gamma) N}{1-\gamma-n F}\right)^{\alpha}, \\
& \frac{\gamma}{v} p=\left(\frac{N^{*}}{1-L^{*}}\right)^{\alpha}=\left(\frac{(1-\gamma) N^{*}}{1-\gamma-n^{*} F}\right)^{\alpha} .
\end{aligned}
$$

Equations (17), (18), and (18*) determine the equilibrium of this model. The three unknowns are $p, n$, and $n^{*}$. Total differentiation yields the comparative static effects of a change in domestic land endowment. We assume that the two countries are symmetric initially, i.e. $n=n^{*}$, before $N$ is changed. Moreover, we use (2), (5), and (6) to simplify some of the elements of the resulting matrix of partial derivatives.

$$
\left(\begin{array}{ccc}
\frac{2 \gamma(1-L)}{v}-\frac{2 A}{\delta p} & \frac{(1-\gamma) A}{\gamma \delta n}-\frac{F w}{1-\gamma} & \frac{(1-\gamma) A}{\gamma \delta n}-\frac{F w}{1-\gamma} \\
\frac{\gamma}{v} & -\frac{\alpha F w}{(1-\gamma)(1-L)} & 0 \\
\frac{\gamma}{v} & 0 & -\frac{\alpha F w}{(1-\gamma)(1-L)}
\end{array}\right)\left(\begin{array}{c}
d p \\
d n \\
d n^{*}
\end{array}\right)=\left(\begin{array}{c}
0 \\
\alpha \frac{w}{N} \\
0
\end{array}\right) d N
$$

Closer inspection of the matrix on the left-hand side yields 


\section{Proposition 3}

Assume that utility is linear manufactured goods. Then an increase in land has ambiguous effects on the price of manufactured goods and on product variety. The changes in the price of manufactured and the number of foreign varieties have the same signs.

Proof: Inspection of the matrix on the left-hand side shows that the sign of its determinant is ambiguous. The adjoints for all three variables have ambiguous signs, too, since the first-row elements of the matrix can be positive or negative.

Explanation. Complex general-equilibrium effects may cause ambiguous results. The changes in prices and the number of foreign varieties display the same sign because the price spill-over from the domestic to the foreign manufactured goods market induces changes in foreign supply.

To illustrate the results, we look at two special cases. Details on the derivation of the results are in Appendix A3. Graphical illustrations of the two scenarios are provided in Figure 2. 


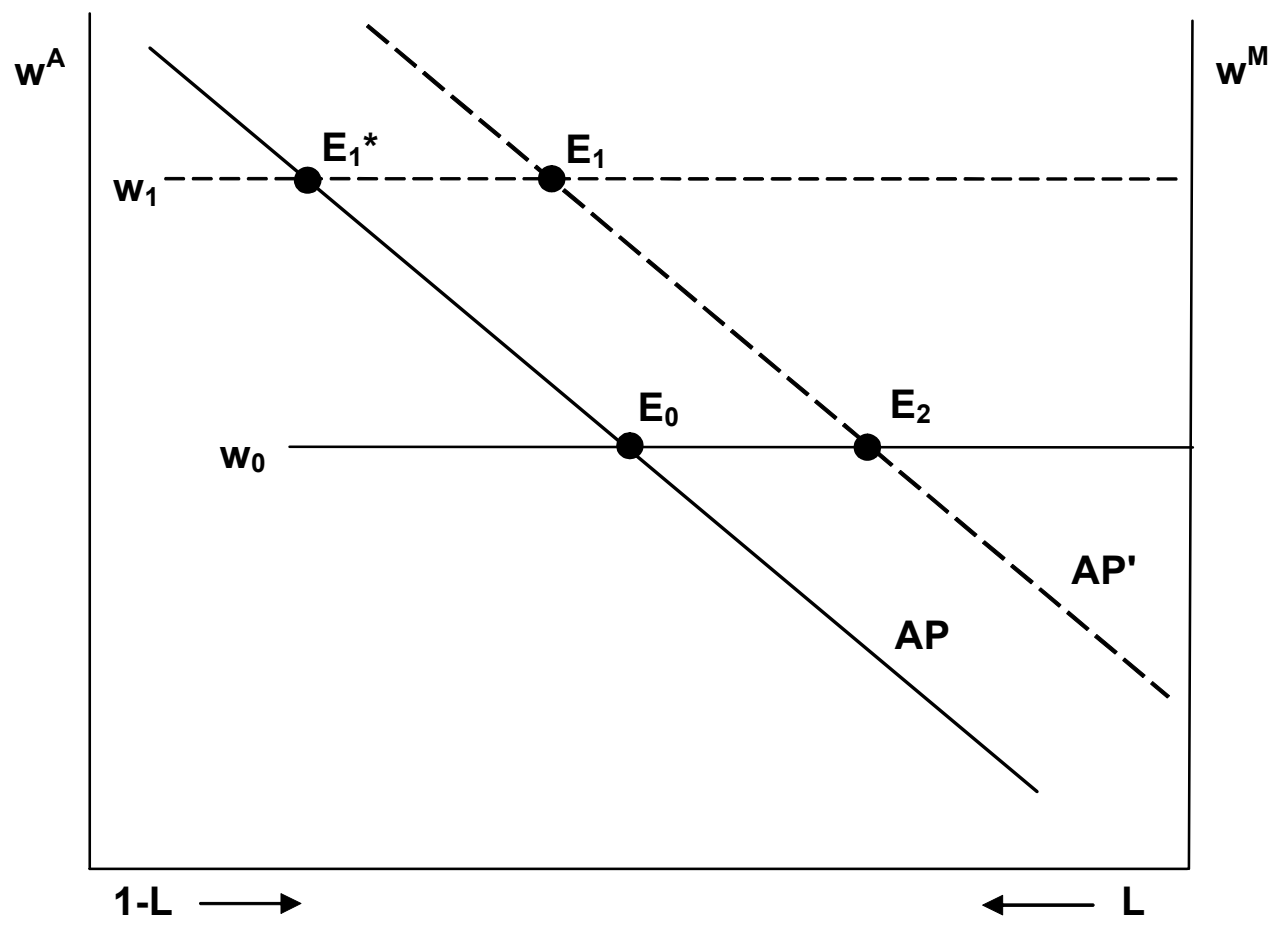

Figure 2: Comparative statics with income dependent demand for manufactured goods

Due to the symmetry assumption, the diagram can represent the comparative static results for both countries. In the home country, the average-productivity curve $(A P)$ is shifted upward; in the foreign country its location is unchanged.

- Case 1: $\delta \rightarrow \infty$. Equation (16d) shows that demand for agricultural goods is very price inelastic for this case. The comparative statics are unambiguous:

$$
\frac{d p}{d N}>0, \frac{d n}{d N}>0, \text { and } \frac{d n^{*}}{d N}>0
$$

Because of the inelastic demand for agricultural products, the price cut necessary to reestablish the equilibrium after the increase in food production due to land expansion is drastic. Relative prices for manufactured goods increase substantially, and manufacturing wages also rise (from $w_{0}$ to $w_{1}$ in Figure 2). Consequently, workers move into the manufacturing sector, and there are more workers in the differentiated-goods sectors of both countries. This leads to an increase in product variety. As depicted in Figure 2, the new equilibrium in the home country is $E_{1}$, whereas the new equilibrium in the foreign country is 
$E_{1}{ }^{*}$. Domestic agricultural output in the home country has increased since the effect of additional land exceeds the effect from the loss of agricultural labor. In addition, the home country is more land-abundant and becomes an agricultural exporter. This means that more agricultural output is also available to the foreign country via trade. Thus, everyone is better off due to the increase in global agricultural output and product variety.

- Case 2: $L=\frac{1-\gamma}{1-\gamma+\delta \gamma}$ in the initial equilibrium. Appendix A3 shows that the second and third-column elements of the matrix on the left-hand side of equation (19) cancel out and, therefore,

$$
\frac{d p}{d N}=0, \frac{d n^{*}}{d N}=0 \text { and } \frac{d n / n}{d N / N}=-\frac{1-L}{L}=-\frac{\delta \gamma}{1-\gamma} .
$$

Thus, it is possible to obtain the same result as in the case of income-independent demand for manufactured goods. As shown in Figure 2, the wage level remains unchanged at $w_{0}$. Consequently, the foreign equilibrium remains the same, but equilibrium for the home country shifts from $E_{0}$ to $E_{2}$. The constancy of the wage is unexpected at a first glance. It can be explained as follows. The first-round effect of the increase in land endowment is an increase in rural income and in the supply of agricultural goods. This implies a rise in the demand and the price of manufactured goods. However, by setting a particular value of $L$, the model has been calibrated such that the effects of product variety on the goods-market equilibrium cancel out. Demand for food is declining in product variety whereas expenditure on manufactured goods is increased. If these effects neutralize each other and the price has changed, the goods market must be in disequilibrium. The equilibrium is reestablished by the price falling back to its original level. If the price is at its original level, however, there are no incentives in the foreign country to produce additional varieties. The degree of domestic product variety is reduced since labor has moved to the rural sector.

Welfare effects can be established easily for the scenario when manufactures are a luxury good: 


\section{Proposition 4}

Assume that all additional income is used for manufactured goods. Then the welfare effects of an increase in land are ambiguous. It is possible that both countries gain and that both countries lose.

Proof. In case 1, both countries are better off as has been shown already. In case 2, both countries lose. The latter result is shown in the appendix (A4).

Explanation. The particular assumptions made about the parameters of the model to construct case 2 have the consequence that the positive impact on welfare of an increase in food consumption is always dominated by the negative impact of the loss of variety.

Thus, we have established that the possibility of bilateral welfare losses is not restricted to the quasilinear version of the model, in which demand for manufactured goods is inelastic. Of course, one would expect that this result carries over to small deviations from quasilinearity, i.e. to scenarios in which this income elasticity is positive, but small. Here, however, we have established that welfare losses are possible even if the income elasticity is large, i.e. if at given prices all additional income is spent on goods produced in the manufacturing sector. The question remains as to whether this result carries over to asymmetric countries. This is the subject of the following section.

\section{North-South Trade}

Do the results of Proposition 4 hold if the assumption of symmetric countries is relaxed, i.e. if we consider a North-South model, in which the North is more productive than the South and in which only the South is characterised by Lewisian surplus labor in the agricultural sector? Let the foreign country be the North. In particular, we assume that

$$
\begin{aligned}
& v^{*}<v \text { and } F^{*}<F \text {, but } F^{*} / v^{*}=F / v, \\
& w^{A}=(1-\alpha)\left(\frac{N^{*}}{1-L^{*}}\right)^{\alpha},
\end{aligned}
$$

and 


$$
r^{*}=\alpha\left(\frac{N^{*}}{1-L^{*}}\right)^{\alpha-1}
$$

where $r^{*}$ is the foreign land rent. Land-rent income, $R^{*}$, is then:

$$
R^{*}=\alpha N^{*}\left(\frac{N^{*}}{1-L^{*}}\right)^{\alpha-1}=\frac{\alpha}{1-\alpha} w^{*}\left(1-L^{*}\right)
$$

The assumption on fixed and variable costs, (20a), implies that the foreign country has a Ricardian comparative advantage in the manufacturing sector but the fixed-to-variable-cost ratio is unchanged. (20b) and (20c) indicate that factor remunerations equal their marginal value products, and (20d) follows from (20c) and the fact that the income shares of workers and land owners in the rural sector are $\alpha$ and 1- $\alpha$, respectively.

The assumption made about the fixed-to-variable-cost ratio implies that equation (6), determining $q$, holds for both countries, i.e. $q=q^{*}$. It then follows from the absence of transportation costs and from the equal substitution elasticities between domestic and foreign manufactured goods that $p=p^{*}{ }^{5}$ For $A$ and $A *$, we still have

$$
A=A^{*}=\left(n+n^{*}\right)^{\frac{\gamma-1}{\gamma \delta}} p^{\frac{1}{\delta}}
$$

but the global economy's budget constraint is now

$$
\left(n+n^{*}\right) p q+2 A=w+w^{*}+R^{*}
$$

Inserting for $A$ from (16d), for $R^{*}$ from (20d), for $w$ and $w^{*}$ from (5) and its foreign analogue, respectively, for $q$ from (6), for $L^{*}$ from (7), and noting that $v / v^{*}=F / F^{*}$ yields

$$
\frac{\gamma}{v} p\left[1+\frac{v}{v^{*}(1-\alpha)}-\frac{F}{(1-\gamma)}\left(n+\frac{n^{*}}{(1-\alpha)}\right)\right]=2\left(n+n^{*}\right)^{\frac{\gamma-1}{\gamma \delta}} p^{\frac{1}{\delta}}
$$

This is a generalisation of (17), where $v / v^{*}>1$ on the left-hand side accounts for the fact that North's wages are larger than South's and the terms $(1-\alpha)$ in the numerators reflect that foreign income contains a land rent, which is not dissipated by average-productivity remuneration of labor.

5 The algebraic deviation of the results of the previous chapter in Appendix A.2 carries over to this case as well. 
Equation (18) remains unchanged, but is now denoted as (23), and its foreign equivalent is changed by a factor $(1-\alpha)$ due to marginal-productivity wages in the foreign agricultural sector. This yields $(23 *)$ :

$$
\begin{aligned}
& \frac{\gamma}{v} p=\left(\frac{N}{1-L}\right)^{\alpha}=\left(\frac{(1-\gamma) N}{1-\gamma-n F}\right)^{\alpha}, \\
& \frac{\gamma}{v^{*}} p=(1-\alpha)\left(\frac{N^{*}}{1-L^{*}}\right)^{\alpha}=(1-\alpha)\left(\frac{(1-\gamma) N^{*}}{1-\gamma-n^{*} F^{*}}\right)^{\alpha} .
\end{aligned}
$$

Assume that both countries are equally endowed with land, $N^{*}=N$. From (23) and (23*), it then follows that

$$
\left(\frac{1-L^{*}}{1-L}\right)^{\alpha}=\left(\frac{1-\gamma-n^{*} F^{*}}{1-\gamma-n F}\right)^{\alpha}=(1-\alpha) \frac{v^{*}}{v}
$$

Since the right-hand side is less than one, $L^{*}>L$. Moreover, since $F^{*}<F$, it follows that $n^{*}>n$. Thus we have:

\section{Proposition 5}

Assume that both countries are equally well endowed with land and that the foreign country has marginal-productivity wages in agriculture and/or a comparative advantage in manfacturing. Then manufacturing employment and the number of varieties are larger in the foreign than in the home country.

Explanation. This is a variant of Ricardo's theorem of comparative advantage. The foreign country specializes in the production the manufactured good, uses more labor in this industry, and produces a larger number of varieties. This effect is reinforced by the absence of surplus labor in the rural sector of the foreign country.

Total differentiation of (22), (23), and (23*) yields

$$
\left(\begin{array}{ccc}
\frac{\gamma}{v}\left[1-L+\frac{v}{v^{*}} \frac{1-L^{*}}{1-\alpha}\right]-\frac{2 A}{\delta p} & \frac{2(1-\gamma) A}{\gamma \delta\left(n+n^{*}\right)}-\frac{F w}{1-\gamma} & \frac{2(1-\gamma) A}{\gamma \delta\left(n+n^{*}\right)}-\frac{F w}{(1-\gamma)(1-\alpha)} \\
\frac{\gamma}{v} & -\frac{\alpha F w}{(1-\gamma)(1-L)} & 0 \\
\frac{\gamma}{v^{*}} & 0 & -\frac{\alpha F^{*} w^{*}}{(1-\gamma)\left(1-L^{*}\right)}
\end{array}\right)\left(\begin{array}{c}
d p \\
d n \\
d n^{*}
\end{array}\right)=\left(\begin{array}{c}
0 \\
\alpha \frac{w}{N} \\
0
\end{array}\right) d N
$$


It is seen that the symmetric case discussed in the previous section is a special case of the NorthSouth model investigated here. The matrix on the left-hand side of (19), representing the symmetric model, is obtained by setting $v^{*}=v, F^{*}=F, L^{*}=L, n^{*}=n, w^{*}=w$ and omitting $(1-\alpha)$ in equation (25). As in the symmetric case, the sign of the determinant of the matrix on the lefthand side is ambiguous.

In order to show that negative welfare effects are possible, construct a case analogous to Case 2 in the previous section of the paper. Assume that the following condition is satisfied:

$$
\frac{2(1-\gamma) A}{\gamma \delta\left(n+n^{*}\right)}=\frac{F w}{1-\gamma}
$$

This implies that the first-row second-column element in the matrix on the left-hand side of (25) vanishes and the following proposition follows:

\section{Proposition 6}

If (26) holds, which is possible for particular combinations of parameters, it follows that $d p / d N=d n * / d N=0$ and $d n / d N<0$. Thus, since relative prices and foreign product variety are unchanged, the loss of domestic product variety implies a welfare loss for both countries as a consequence of an increase in domestic land endowment.

Proof. If (26) holds, then the adjoints of the matrix in (25) for $d p / d N$ and $d n * / d N$ vanish and $\frac{d n}{d N}=-\frac{F N}{(1-\gamma)(1-L)}$. Appendix A4 can be used to show that, despite the increase in resources, welfare is negatively affected. The results derived for the symmetric case carry over to the North-South model. It remains to be shown that condition (26) is feasible. This is done in Appendix A5.

Thus, it has been shown that the result derived initially for a world with identical countries with agricultural surplus labor and income-inelastic demand for manufactured goods generalizes to a North-South model of international trade in which demand for manufactured goods is very income elastic. Increased availability of natural resources may deteriorate welfare. 


\section{Final Remarks}

The paper has shown that agricultural development is not always beneficial to an open economy - and to its trading partner as well. The underlying reason is that, due to income and price effects the agricultural expansion may lead to a loss of manufacturing output. This reduces product variety and, if consumers value variety, welfare, too. We started from a very simple version of the model with quasilinear preferences and symmetric countries and were able to show that the results carry over to scenarios that are more complex and more realistic.

In our model, additional land fell from heaven like manna. This might be realistic for an economy like the US in the 19th century, which expanded westwards and appropriated open land until the Pacific Coast was reached. In developing countries, however, land expansion often involves substantial social costs, in particular if the new land is gained by clear-cutting tropical forests, consequences being soil degradation, flooding, changing of local climates and biodiversity loss. Of course, such social costs, if not internalized, add another second-best component to the model which makes land development even more harmful. As already mentioned, another interpretation of our land-expansion model is technological progress in the agricultural sector. This progress does also not come about automatically but requires the use of scarce factors of production. This cost has been neglected in our model. However, we have shown that the country may still be worse off if the technological improvements are transferred for free, e.g. in terms of foreign development aid.

Nevertheless the results are still limited due to the comparative-static nature of the model. In reality, development is not restricted to the expansion of agriculture but is embedded in a more general development process in which manufacturing productivity is increased as well. We do not think, however, that the basic message of the paper would be altered if the land expansion issue would be discussed in the framework of a dynamic development model that explicitly deals with economic growth. Again, a faster development of the agricultural sector can be harmful to the economy.

Despite its limitations, the model developed in this paper produces two alternative frontier-led development outcomes that may accord with two different historical eras in which such development was prominent. 
The first era occurred during the "Golden Age of Resource-Based Development" of 1870-1914, Findlay and Lundahl (1999, p. 16) note that all four "regions of recent settlement" during the Golden Age, Argentina, Australia, Canada and the United States, displayed a similar pattern of economic development: "All of them based their export activities on the existence of an unexploited land frontier, all of them received both capital and labor from abroad and all of them were in the process of industrializing as World War I broke out." For these four countries during the Golden Age, the "win-win" result obtained by one version of our model where agricultural land expansion leads to both a rise in agricultural output and exports as well as expansion of manufacturing production and employment appears to be appropriate. In essence, for these four economies the optimistic "growth takeoff" of the original labor surplus model of Lewis (1954) occurred, but through the process of land expansion as depicted in our model and not through population growth as the original Lewis model suggested. What is more, as predicted by our model, during the Gold Age there was a general world economic boom, in which the "industrial core" of Western Europe also benefited from manufacturing expansion and trade with primary-product exporters (Taylor and Williamson 1994). A recent study pointing to the empirical relevance of our results is Francois, van Meijl and van Tongeren (2005). They analyze the effects of global trade liberalization by means of a computable general equilibrium model that includes aspects of product diversity and intra-industry trade and find that China will lose due to unfavorable patterns of specialization. It is shown that China will expand its textile industry at the expense of the metal and electrotechnical industries, where increasing returns to scale and product diversity are more pronounced. The textile industry in their empirical study corresponds to the rural sector in this paper. This indicates that our considerations concerning agriculture may well generalize to other traditional sectors that are characterized by product homogeneity and absence of substantial returns to scale.

Frontier agricultural expansion is also prominent in the current era for many of the poorest economies of the world, which are located predominantly in tropical regions. However, for these countries frontier land expansion appears to be serving mainly as an outlet for the rural poor, and is symptomatic of a pattern of economy-wide resource exploitation that: a) generates little additional rents, and b) what rents are generated tend to be dissipated rather than reinvested in more productive and dynamic sectors, such as manufacturing (Barbier 2005). As a consequence, in present-day developing economies frontier land expansion and resource 
exploitation is less likely to be associated with successful economic development. ${ }^{6}$ This outcome is perhaps best captured in our model scenario where, for the home country at least, any increase in agricultural goods from frontier land expansion fails to compensate for the decline in manufacturing varieties produced domestically. The country specializes in but fails to benefit from land-extensive exports, and the manufacturing sector may actually decline. This outcome corresponds to the "immiserizing growth" outcome from increased agricultural productivity as analyzed by Matsuyama (1992); however, once again the source of the increase in productivity is an expansion in the agricultural land endowment as depicted in our model.

Since we used a trade model to derive our results, the question arises whether trade restrictions are advisable in cases where land expansion generates harmful welfare results. Two cases have to be distinguished here. The first case is closely related to what has been analyzed in this paper: the land expansion is exogenous. With exogenous land expansion, the results for the land-expanding country carry over to the closed economy - at least qualitatively. The other country of course can insulate its economy from shocks in the rest of the world by being autarchic. However, having no trade at all is worse than trading with a land-expanding country. The other case is the one in which trade liberalization causes land expansion. This is what freetraders have in mind when they argue that industrialized countries should give up protection of their agricultural markets to open new perspectives for developing countries. Of course, the issue cannot be dealt within the framework of our model since endogenous land expansion, requiring scarce resources, is outside the scope of our model. This is an interesting question for future research. Our intuition is that trade is better than autarky, but that in some situations restricted trade may be better than free trade.

Thus, a policy conclusion from our paper is that land expansion and the strive for productivity increases in agriculture may be harmful not only to the country under consideration but also to its trading partners if agricultural development is not accompanied by development of manufacturing industries as well. A path of trade liberalization that leads to large expansion of agricultural production in developing countries may be welfare-deteriorating.

\footnotetext{
${ }^{6}$ For example, Barbier (2005) provides statistical evidence of a negative correlation between gross domestic product (GDP) per capita and a measure of long-run agricultural expansion over 1961-1994 for all tropical countries and for low and lower middle-income tropical countries.
} 


\section{Appendix}

\section{A.1 Proof of Proposition 2}

The welfare function is changed such that

$$
U=r N+w+\frac{1-\gamma}{\gamma}\left(n p^{\frac{\gamma}{\gamma-1}}+n^{*} p^{\frac{\gamma}{\gamma-1}}\right) .
$$

Its derivative with respect to $N$, noting that $r, w, p, n^{*}$, and $p^{*}$ are constant and using (12b) for $d n / d N$ is

$$
\frac{d U}{d N}=r-\frac{(1-\gamma)^{2}(1-L)}{\gamma F N} p^{\frac{\gamma}{\gamma-1}}
$$

To show ambiguity, a numerical example is sufficient. Thus assume, $v=(1-\alpha) \gamma$ and $F=2(1-\alpha)(1-\gamma)$. From (10), we have that $p=1$ and from (5) that $w=1-\alpha$. From (13a) we then have $1-L=N$. Then $r=\alpha$. Thus,

$$
\frac{d U}{d N}=\alpha-\frac{(1-\gamma)^{2}}{\gamma F}=\alpha-\frac{1-\gamma}{2 \gamma(1-\alpha)} .
$$

If $\gamma$ is close to 1 , i.e. if different varieties are good substitutes, the welfare effect is positive. If $\gamma$ is close to zero, i.e. if substitutability is low, then it is negative.

\section{A.2 Derivation of Equations (16a-e)}

Using a Lagrangean approach to maximize utility, (14), subject to the budget constraint, (9), the first-order conditions of utility maximization are:

$$
\begin{aligned}
& A^{-\delta}=\lambda, \\
& c^{\gamma-1}\left(n c^{\gamma}+n * m^{\gamma}\right)^{\frac{1-\gamma}{\gamma}}=\lambda p, \\
& m^{\gamma-1}\left(n c^{\gamma}+n^{*} m^{\gamma}\right)^{\frac{1-\gamma}{\gamma}}=\lambda p^{*},
\end{aligned}
$$


with $\lambda$ as the Lagrangean multiplier. The usual techniques, described for instance in Baldwin et al. (2003), are employed to eliminate $\lambda$. This gives the domestic consumer demand functions for domestic and foreign manufactured goods.

$$
\begin{gathered}
c=\frac{(w-A) p^{\frac{1}{\gamma-1}}}{n p^{\frac{\gamma}{\gamma-1}}+n^{*} p^{\frac{\gamma}{\gamma-1}}} \\
m=\frac{(w-A) p^{* \frac{1}{\gamma-1}}}{n p^{\frac{\gamma}{\gamma-1}}+n^{*} p^{\frac{\gamma}{\gamma-1}}}
\end{gathered}
$$

The numerator contains a variant of the price index that occurs generally in Dixit-Stiglitz-type models. (A4) and (A5) and their foreign analogues can be used to determine market demand functions for individual varieties using $q=c+m^{*}$ and $q^{*}=c^{*}+m$.

$$
\begin{gathered}
q=\frac{w-A+w^{*}-A^{*}}{n p^{\frac{\gamma}{\gamma-1}}+n^{*} p^{\frac{\gamma}{\gamma-1}} p^{\frac{1}{\gamma-1}},} \\
q^{*}=\frac{w-A+w^{*}-A^{*}}{n p^{\frac{\gamma}{\gamma-1}}+n^{*} p^{\frac{\gamma}{\gamma-1}}} p^{\frac{1}{\gamma-1}} .
\end{gathered}
$$

The fractions on the right hand sides contain the general price index in the denominator and the income to be spent on manufactured goods in the numerator. From the point of view of an individual producer, these terms are taken as given such that the single firms still face inverse market demand curves $p=\xi q^{\gamma-1}$ and $p^{*}=\xi q^{*-1}$. They are identical for the two countries and, thus, $q=q^{*}$ implies $p^{*}=p$. In a symmetric equilibrium, the equality of prices implies $w=w^{*}$ via equation (2).

Using the equality of prices in the two countries, (A4) and (A5) can be rewritten:

$$
c=m=\frac{w-A}{\left(n+n^{*}\right) p}
$$




$$
c^{*}=m^{*}=\frac{w^{*}-A^{*}}{\left(n+n^{*}\right) p}
$$

Using $p=p *$ in (A6) yields:

$$
p=\frac{w-A+w^{*}-A^{*}}{\left(n+n^{*}\right) q}
$$

$A$ is obtained from via (A1) and (A2). After eliminating the shadow price $\lambda$, one can use (A7) to substitute for $c$ and $m$.

$$
A=\left(n+n^{*}\right)^{\frac{\gamma-1}{\gamma \delta}} p^{\frac{1}{\delta}}
$$

$A=A^{*}$ follows from the fact that $p=p^{*}$.

\section{A3 Results for the special cases in Section 3}

Case 1: $\delta \rightarrow \infty$. The terms in the first row containing $\delta$ vanish, such that (19) becomes

$$
\left(\begin{array}{ccc}
\frac{2 \gamma(1-L)}{v} & -\frac{F w}{1-\gamma} & -\frac{F w}{1-\gamma} \\
\frac{\gamma}{v} & -\frac{\alpha F w}{(1-\gamma)(1-L)} & 0 \\
\frac{\gamma}{v} & 0 & -\frac{\alpha F w}{(1-\gamma)(1-L)}
\end{array}\right)\left(\begin{array}{c}
d p \\
d n \\
d n *
\end{array}\right)=\left(\begin{array}{c}
0 \\
\alpha \frac{w}{N} \\
0
\end{array}\right) d N
$$

The determinant of the matrix on the left-hand side, $H_{1}$, is

$$
\operatorname{det} H_{1}=-\frac{2(1-\alpha) \alpha \gamma(F w)^{2}}{(1-\gamma)^{2} v(1-L)}<0
$$

It then follows that $\frac{d p}{d N}>0, \frac{d n}{d N}>0$, and $\frac{d n^{*}}{d N}>0$.

Case 2: $L=\frac{1-\gamma}{1-\gamma+\delta \gamma}$. This can be rewritten as $(1-\gamma)(1-L)=\delta \gamma L$. In the symmetric initial equilibrium, agricultural goods are not traded internationally. Thus, due to average-productivity wages, the income of rural workers equals the domestic demand for agricultural commodities: 
$(1-L) w=A$. Using this to substitute for $(1-L)$ implies $\frac{(1-\gamma) A}{\delta \gamma w}-L=0$. Using (7) to substitute for $L$, we obtain $\frac{(1-\gamma) A}{\delta \gamma w}-\frac{n F}{1-\gamma}=0$. Thus the second and third column elements of the first row of the matrix vanish. This implies that $\frac{d p}{d N}$ and $\frac{d n^{*}}{d N}$ are zero and $\frac{d n}{d N}=-\frac{(1-\gamma)(1-L)}{F N}$. Using (6), this can be rewritten: $\frac{d n / n}{d N / N}=-\frac{1-L}{L}$.

\section{A4 Welfare Effects for Case 2}

The indirect utility function in the home country is determined by using (A7) in (15):

$$
U=\frac{A^{1-\delta}-1}{1-\delta}+(n+n *) \frac{1-\gamma}{\gamma} \frac{w-A}{p}
$$

The welfare effect consists of two components. There is a direct effect from the change in $n$ and an indirect effect via the consumption of agricultural goods. Thus:

$$
\frac{d U}{d N}=\left(\frac{1-\gamma}{\gamma}(n+n *)^{\frac{1-2 \gamma}{\gamma}} \frac{w-A}{p}+\left(A^{-\delta}-\frac{(n+n *)^{\frac{1-\gamma}{\gamma}}}{p}\right) \frac{d A}{d n}\right) \frac{d n}{d N},
$$

where $d A / d n$ follows from (16d). However, the term in brackets in front of $d A / d n$ is zero. This follows from utility maximization. A formal proof consists of inserting for $c$ and $m$ in (A2). It follows that $\lambda p=(n+n *)^{\frac{1-\gamma}{\gamma}}$. Thus the term in brackets is reduced to $A^{-\delta}-\lambda$. This is zero due to the first-order condition (A1). Thus the welfare effect is

$$
\frac{d U}{d N}=\frac{1-\gamma}{\gamma}(n+n *)^{\frac{1-2 \gamma}{\gamma}} \frac{w L}{p} \frac{d n}{d N},
$$

where $w(1-L)$ has been used for $A . d U / d N$ is strictly negative.

This result carries over to the foreign country because of symmetry. In the asymmetric case considered in Section 5, the foreign country's indirect utility function turns out to be

$$
U=\frac{A^{1-\delta}-1}{1-\delta}+\left(n+n^{*}\right)^{\frac{1-\gamma}{\gamma}} \frac{w^{*}+R^{*}-A}{p},
$$


where $R^{*}$ is the land-rent income. Since wage rate and land rent are unaffected by land expansion in the home country if prices are constant, the comparative static results carry over from the home country to the foreign country even in the asymmetric case.

\section{A5 Feasibility of condition (26)}

It is to be shown that the condition

$$
\frac{2(1-\gamma) A}{\gamma \delta\left(n+n^{*}\right)}=\frac{F w}{1-\gamma}
$$

is feasible and in particular that it does not contradict (24), which determines $L^{*}$ as a function of $L$, and $n^{*}$ as a function of $n$. Assume the following parameters:

$$
\alpha=\gamma=F=\frac{v^{*}}{v}=\frac{1}{2} .
$$

This implies $F^{*}=1 / 4$. Moreover assume that the home country does not produce the manufactured good, but nevertheless all the monopolistic-competition first-order conditions hold. I.e. the manufacturing sector is a marginal sector in the sense that the first domestic producer entering this market would make a zero profit. Thus,

$$
n=L=0 .
$$

Using (A.10) and (A.11) in equation (24) yields

$$
L^{*}=\frac{15}{16} \text { and } n^{*}=\frac{15}{8} .
$$

Euqation (26) can be rewritten by using $n=0$ inserting form (21) for $2 A$ :

$$
w+w^{*}+R^{*}-n^{*} p q=\frac{\gamma \delta F n * w}{(1-\gamma)^{2}} .
$$

Dividing by $w$ on both sides, using (5) to eliminate $p$, (6) to eliminate $q$, (20d) to substitute for $R^{*}$ and noting that $w^{*} / w=v / v^{*}$ yields

$$
1+\frac{v}{v^{*}}+\frac{\alpha}{1-\alpha} \frac{v}{v^{*}}\left(1-L^{*}\right)-\frac{F n^{*}}{1-\gamma}=\frac{\gamma \delta F n^{*}}{(1-\gamma)^{2}}
$$

Using the assumptions about parameters, (A10), and (A11) yields 


$$
1+2+\frac{1}{8}-\frac{15}{8}=\frac{15 \delta}{8}
$$

and it follows that $\delta=\frac{2}{3}$. Thus, there exists a combination of parameters such that (26) is satisfied. Of course, it is possible to find a continuum of other parameter combinations such that (26) holds. 


\section{References}

Baldwin, Richard, Rikard Forslid, Philippe Martin, Gianmarco Ottaviano, and Frederic RobertNicoud 2003. Economic Geography and Public Policy; Princeton: Princeton University Press.

Barbier, Edward B. 2005. "Frontier Expansion and Economic Development." Contemporary Economic Policy 23(2):286-303.

Burgstaller, André and Nicolás Saavedra Rivano. 1984. "Capital Mobility and Growth in a North-South Model." Journal of Development Economics 15:213-237.

Dixit, Avinash, and Joseph E. Stiglitz 1977. "Monopolistic Competition and Optimum Product Diversity." American Economic Review 67: 297-308.

Findlay, Ronald. 1980. "The Terms of Trade and Equilibrium Growth in the World Economy." American Economic Review 70:291-299.

Findlay, Ronald. 1992. "The Roots of Divergence: Western Economic History in Comparative Perspective." American Economic Review 82(2):158-161.

Findlay, Ronald and Mats Lundahl. 1999. "Resource-Led Growth - a Long-Term Perspective: The Relevance of the 1870-1914 Experience for Today's Developing Economies." UNU/WIDER Working Papers No. 162. World Institute for Development Economics Research, Helsinki.

Francois, Joseph, Hans van Meijl and Frank van Tongeren, 2005. " Trade liberalization in the Doha Development Round", Economic Policy 20, 349-381.

Johnson, Harry G., 1967. "The Possibility of Income Losses from Increased Efficiency or Factor Accumulation in the Presence of Tariffs, Economic Journal 77, 151-154.

Krugman, Paul R. 1979. "Increasing Returns, Monopolistic Competition, and International Trade." Journal of International Economics 9: 469-479.

Krugman, Paul R. 1980, "Scale Economies, Product Differentiation and the Pattern of Trade." American Economic Review: 67, 298-307.

Krugman, Paul R. 1981. "Trade, Accumulation, and Uneven Development." Journal of Development Economics 8:149-161.

Lewis, W. Arthur. 1954. "Economic Development with Unlimited Supplies of Labor." Manchester School 22, 139-191.

Matsuyama, Kimoru 1992. "Agricultural Productivity, Comparative Advantage, and Economic Growth." Journal of Economic Theory 58: 317-334.

Taylor, Alan M. and Jeffrey G. Williamson. 1994. "Capital Flows to the New World as an Intergenerational Transfer.” Journal of Political Economy 102(2):348-371. 


\section{CESifo Working Paper Series}

(for full list see www.cesifo-group.de)

1413 Gil S. Epstein and Shmuel Nitzan, Lobbying and Compromise, February 2005

1414 Marcel F. M. Canoy, Jan C. van Ours and Frederick van der Ploeg, The Economics of Books, February 2005

1415 Eric A. Hanushek and Ludger Wößmann, Does Educational Tracking Affect Performance and Inequality? Differences-in-Differences Evidence across Countries, February 2005

1416 George Kapetanios and M. Hashem Pesaran, Alternative Approaches to Estimation and Inference in Large Multifactor Panels: Small Sample Results with an Application to Modelling of Asset Returns, February 2005

1417 Samuel Mühlemann, Jürg Schweri, Rainer Winkelmann and Stefan C. Wolter, A Structural Model of Demand for Apprentices. February 2005

1418 Giorgio Brunello and Lorenzo Rocco, Educational Standards in Private and Public Schools, February 2005

1419 Alex Bryson, Lorenzo Cappellari and Claudio Lucifora, Why so Unhappy? The Effects of Unionisation on Job Satisfaction, March 2005

1420 Annalisa Luporini, Relative Performance Evaluation in a Multi-Plant Firm, March 2005

1421 Giorgio Bellettini and Carlotta Berti Ceroni, When the Union Hurts the Workers: A Positive Analysis of Immigration Policy, March 2005

1422 Pieter Gautier, Michael Svarer and Coen Teulings, Marriage and the City, March 2005

1423 Ingrid Ott and Stephen J. Turnovsky, Excludable and Non-Excludable Public Inputs: Consequences for Economic Growth, March 2005

1424 Frederick van der Ploeg, Back to Keynes?, March 2005

1425 Stephane Dees, Filippo di Mauro, M. Hashem Pesaran and L. Vanessa Smith, Exploring the International Linkages of the Euro Area: a Global VAR Analysis, March 2005

1426 Hans Pitlik, Friedrich Schneider and Harald Strotmann, Legislative Malapportionment and the Politicization of Germany’s Intergovernmental Transfer System, March 2005

1427 Konstantinos Angelopoulos and Apostolis Philippopoulos, The Role of Government in Anti-Social Redistributive Activities, March 2005

1428 Ansgar Belke and Daniel Gros, Asymmetries in the Trans-Atlantic Monetary Policy Relationship: Does the ECB follow the Fed?, March 2005 
1429 Sören Blomquist and Luca Micheletto, Optimal Redistributive Taxation when Government’s and Agents’ Preferences Differ, March 2005

1430 Olof Åslund and Peter Fredriksson, Ethnic Enclaves and Welfare Cultures - QuasiExperimental Evidence, March 2005

1431 Paul De Grauwe, Roberto Dieci and Marianna Grimaldi, Fundamental and NonFundamental Equilibria in the Foreign Exchange Market. A Behavioural Finance Framework, March 2005

1432 Peter Egger, Stefan Gruber, Mario Larch and Michael Pfaffermayr, Knowledge-Capital Meets New Economic Geography, March 2005

1433 George Economides and Apostolis Philippopoulos, Should Green Governments Give Priority to Environmental Policies over Growth-Enhancing Policies?, March 2005

1434 George W. Evans and Seppo Honkapohja, An Interview with Thomas J. Sargent, March 2005

1435 Helge Berger and Volker Nitsch, Zooming Out: The Trade Effect of the Euro in Historical Perspective, March 2005

1436 Marc-Andreas Muendler, Rational Information Choice in Financial Market Equilibrium, March 2005

1437 Martin Kolmar and Volker Meier, Intra-Generational Externalities and InterGenerational Transfers, March 2005

1438 M. Hashem Pesaran and Takashi Yamagata, Testing Slope Homogeneity in Large Panels, March 2005

1439 Gjermund Nese and Odd Rune Straume, Industry Concentration and Strategic Trade Policy in Successive Oligopoly, April 2005

1440 Tomer Blumkin and Efraim Sadka, A Case for Taxing Education, April 2005

1441 John Whalley, Globalization and Values, April 2005

1442 Denise L. Mauzerall, Babar Sultan, Namsoug Kim and David F. Bradford, Charging $\mathrm{NO}_{x}$ Emitters for Health Damages: An Exploratory Analysis, April 2005

1443 Britta Hamburg, Mathias Hoffmann and Joachim Keller, Consumption, Wealth and Business Cycles in Germany, April 2005

1444 Kohei Daido and Hideshi Itoh, The Pygmalion Effect: An Agency Model with Reference Dependent Preferences, April 2005

1445 John Whalley, Rationality, Irrationality and Economic Cognition, April 2005

1446 Henning Bohn, The Sustainability of Fiscal Policy in the United States, April 2005 
1447 Torben M. Andersen, Is there a Role for an Active Fiscal Stabilization Policy? April 2005

1448 Hans Gersbach and Hans Haller, Bargaining Power and Equilibrium Consumption, April 2005

1449 Jerome L. Stein, The Transition Economies: A NATREX Evaluation of Research, April 2005

1450 Raymond Riezman, John Whalley and Shunming Zhang, Metrics Capturing the Degree to which Individual Economies are Globalized, April 2005

1451 Romain Ranciere, Aaron Tornell and Frank Westermann, Systemic Crises and Growth, April 2005

1452 Plutarchos Sakellaris and Focco W. Vijselaar, Capital Quality Improvement and the Sources of Growth in the Euro Area, April 2005

1453 Kevin Milligan and Michael Smart, Regional Grants as Pork Barrel Politics, April 2005

1454 Panu Poutvaara and Andreas Wagener, To Draft or not to Draft? Efficiency, Generational Incidence, and Political Economy of Military Conscription, April 2005

1455 Maurice Kugler and Hillel Rapoport, Skilled Emigration, Business Networks and Foreign Direct Investment, April 2005

1456 Yin-Wong Cheung and Eiji Fujii, Cross-Country Relative Price Volatility: Effects of Market Structure, April 2005

1457 Margarita Katsimi and Thomas Moutos, Inequality and Relative Reliance on Tariffs: Theory and Evidence, April 2005

1458 Monika Bütler, Olivia Huguenin and Federica Teppa, Why Forcing People to Save for Retirement may Backfire, April 2005

1459 Jos Jansen, The Effects of Disclosure Regulation of an Innovative Firm, April 2005

1460 Helge Bennmarker, Kenneth Carling and Bertil Holmlund, Do Benefit Hikes Damage Job Finding? Evidence from Swedish Unemployment Insurance Reforms, May 2005

1461 Steffen Huck, Kai A. Konrad and Wieland Müller, Merger without Cost Advantages, May 2005

1462 Louis Eeckhoudt and Harris Schlesinger, Putting Risk in its Proper Place, May 2005

1463 Hui Huang, John Whalley and Shunming Zhang, Trade Liberalization in a Joint Spatial Inter-Temporal Trade Model, May 2005

1464 Mikael Priks, Optimal Rent Extraction in Pre-Industrial England and France - Default Risk and Monitoring Costs, May 2005 
1465 François Ortalo-Magné and Sven Rady, Heterogeneity within Communities: A Stochastic Model with Tenure Choice, May 2005

1466 Jukka Pirttilä and Sanna Tenhunen, Pawns and Queens Revisited: Public Provision of Private Goods when Individuals make Mistakes, May 2005

1467 Ernst Fehr, Susanne Kremhelmer and Klaus M. Schmidt, Fairness and the Optimal Allocation of Ownership Rights, May 2005

1468 Bruno S. Frey, Knight Fever - Towards an Economics of Awards, May 2005

1469 Torberg Falch and Marte Rønning, The Influence of Student Achievement on Teacher Turnover, May 2005

1470 John Komlos and Peter Salamon, The Poverty of Growth with Interdependent Utility Functions, May 2005

1471 Hui Huang, Yi Wang, Yiming Wang, John Whalley and Shunming Zhang, A Trade Model with an Optimal Exchange Rate Motivated by Current Discussion of a Chinese Renminbi Float, May 2005

1472 Helge Holden, Lars Holden and Steinar Holden, Contract Adjustment under Uncertainty, May 2005

1473 Kai A. Konrad, Silent Interests and All-Pay Auctions, May 2005

1474 Ingo Vogelsang, Electricity Transmission Pricing and Performance-Based Regulation, May 2005

1475 Spiros Bougheas and Raymond Riezman, Trade and the Distribution of Human Capital, June 2005

1476 Vesa Kanniainen, Seppo Kari and Jouko Ylä-Liedenpohja, The Start-Up and Growth Stages in Enterprise Formation: The "New View" of Dividend Taxation Reconsidered, June 2005

1477 M. Hashem Pesaran, L. Vanessa Smith and Ron P. Smith, What if the UK had Joined the Euro in 1999? An Empirical Evaluation Using a Global VAR, June 2005

1478 Chang Woon Nam and Doina Maria Radulescu, Effects of Corporate Tax Reforms on SMEs’ Investment Decisions under the Particular Consideration of Inflation, June 2005

1479 Panos Hatzipanayotou, Sajal Lahiri and Michael S. Michael, Globalization, CrossBorder Pollution and Welfare, June 2005

1480 John Whalley, Pitfalls in the Use of Ad valorem Equivalent Representations of the Trade Impacts of Domestic Policies, June 2005

1481 Edward B. Barbier and Michael Rauscher, Trade and Development in a Labor Surplus Economy, June 2005 